
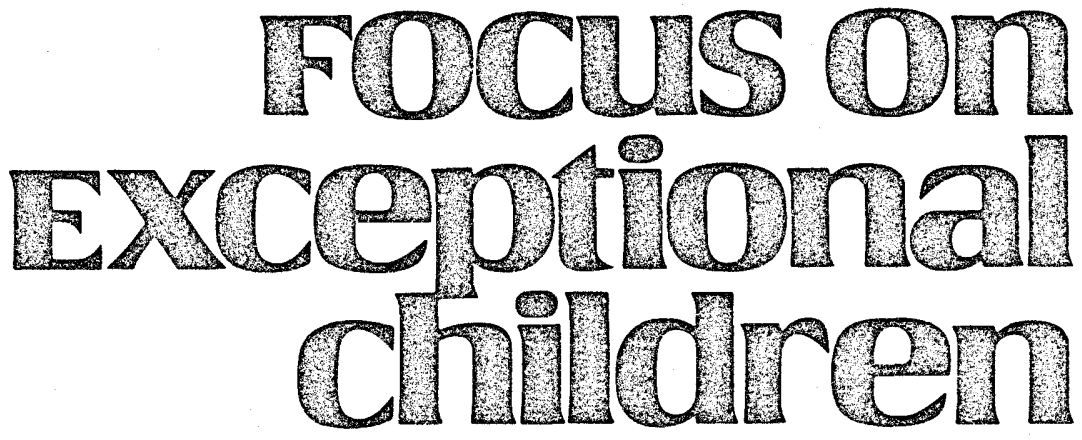

\title{
The Emotional Development of Exceptional Students
}

Henry Dupont

Over the past 20 years, working in the Piagetian child development paradigm, I have constructed a stage-referenced theory and model of emotional development. In the theory, emotions are seen as personal-social constructions that undergo a sequence of transformations in the course of development. Several of the assumptions providing the foundation for this work seem worth mentioning:

1. All behavior has two essential characteristics - one cognitive or structural, and one affective, having to do with energy. Both cognition and affect are adaptive.

2. Each of us is both an agent and an object. As an agent, we structure our personal identities and our worlds of other agents and objects.

3. Emotions are personal-social constructions having three components: a cognitive appraisal, an alteration of affect, and a terminal action.

4. Development is a product of maturation, physical and social experience, and self-regulation.

5. Human infants become human beings in relationships with other human beings and in no other way.

My research confirms the idea that emotional development is intimately related to the development of our personal identity. Emotions occur when we appraise some event or situation as enhancing or threatening our personal identity. There is then, at the core of every emotion, a different personal identity issue. As an example, the core issues for six emotions are shown in Table 1.

Dr. Dupont is the editor of Educating Emotionally Disturbed Children: Readings, 1969; 1975; and was formerly Chairperson, Department of Special Education, University of Hawaii. Now semi-retired, he resides at 5000 Fond Du Lac Court, Stone Mountain, GA 30088.

(C) Love Publishing Company, 1989. 
TABLE 1

The Core Issues for Six Emotions

\begin{tabular}{|c|c|}
\hline Emotion & Core Issue \\
\hline Joy & $\begin{array}{l}\text { Getting or achieving } \\
\text { something valued }\end{array}$ \\
\hline Anger & $\begin{array}{l}\text { Threat to security or } \\
\text { identity }\end{array}$ \\
\hline Guilt & Having done wrong \\
\hline Sadness & Personal loss or failure \\
\hline Pride & Having done well \\
\hline Fear & $\begin{array}{l}\text { Threat to physical well- } \\
\text { being }\end{array}$ \\
\hline
\end{tabular}

\section{Focus on
Exceptional children}

FOCUS ON EXCEPTIONAL CHILDREN (ISSN0015-5IIX) (USPS 203-360) is published monthly except June, July, and August as a service to teachers, special educators, curriculum specialists, administrators, and those concerned with the special education of exceptional children. This publication is annotated and indexed by the ERIC Clearinghouse on Handicapped and Gifted Children for publication in the monthly Current Index to Journals in Education (CIJE) and the quarterly. index, Exceptional Children Education Resources (ECER). It is also available in microform from Xerox University Microfilms, Ann Arbor, MI. Subscription rates: Individuals, $\$ 24$ per year; institutions, $\$ 30$ per year. Copyright (C) 1989 , Love Publishing Company. All rights reserved. Reproduction in whole or part without written permission is prohibited. Printed in the United States of America. Second class postage is paid at Denver, Colorado.

POSTMASTER: Send address changes to:

Love Publishing Company

Executive and Editorial Office

1777 South Bellaire Street

Denver, Colorado 80222

Telephone (303) 757-2579

Edward L. Meyen

University of Kansas
Glenn A. Vergason

Georgia State University

Richard J. Whelan

University of Kansas Medical Center

Stanley F. Love Publisher
Carolyn Acheson Senior Editor
Because it is not what actually happens to us but, rather, our evaluation of the meaning that these events have for us that determines our emotional response, cognitive theories of emotion are gaining increasing acceptance (Arnold, 1960; Averill, 1980; Beck, 1976; Dupont, 1978a; Lazarus, 1982, 1984; Lazarus, Kanner, \& Folkman, 1980). These cognitive theories have in common the idea that every emotion begins with the cognitive evaluation of the event, situation, or object being confronted. There is also general agreement that the nature of our re-action and the energy (affect) we invest in this re-action is a function of our evaluation of the significance this event has for us. Several of us have suggested that the re-action must be included as an integral part of every emotion.

This inclusion of the entire re-action- both our affective and behavioral reactions as an integral part of each emotion - enables us to place emotions very comfortably into the Piagetian child development paradigm. Our emotions then can be seen as transitional adaptations to our ever-changing environment (Dupont, 1989).

\section{EMOTIONS AS TRANSITIONAL ADAPTATIONS}

The somatic (affective) component of every emotion is present as part of our biological inheritance. It is shaped in our social interactions; its function is to energize the actions we undertake to restore, maintain, or enhance our sense of well-being in the context of our environment.

Emotions then, are transitional episodes with cognitive, affective, and behavioral components. They serve a very important function in our lives: They help us maintain and enhance our sense of well-being. They help us develop, protect, and restore our personal identities.

What we feel happy, sad, angry, guilty, afraid of, or proud about, and what we do when we feel that way, is one of our most salient characteristics. My research shows that what we have feelings about and what we do when we have feelings is what changes in the course of development.

What this means - and I want to stress this because it is different from the conventional wisdom - is that although each of these feelings has a core identity issue, the way the issue is confronted and dealt with is substantially different at $5,10,15$, or 20 years of age. For example, my research shows that there are age-related changes in what we get angry about and what we do when we are 
angry. The following responses to anger from different age subjects illustrate this change:

7-year-old boy: Why angry? Cuz my brother got
something and I didn't.
What do? I started to cry.

10-year-old boy: Why angry? Cuz we lost the game. What do? Tease the kids who won.

14-year-old boy: Why angry? I was angry because I wasn't playing very well in a basketball game.

What do? I just tried my best to get back with the flow.

17-year-old boy: Why angry? When I heard a liberal pacifist congressman denouncing our involvement in Cental America and also calling Colonel North a criminal and also ridiculing our President about not being able to recall what he was doing on a certain date approximately a year ago. This makes me angry because it shows a lack of patriotism, and it's pitiful because leaders are advocating that attitude.

What do? I argued with my father (who happens to think in the same manner as the liberal congressman) on the topic, and I vented my anger that way.

Notice that in each of these responses is a threat to the subject's identity or sense of well-being. For the 7-yearold, it was a brother getting something he didn't get. For the 10-year-old, it was losing a game. For the 14-year-old, it was not playing well. And for the 17-year-old, it was someone saying things he believed to be unpatriotic.

Notice, too, how much more abstract and complex the reasons for being angry become with increasing age. Then notice how much more adaptive the older boys' reactions are. The 7-year-old cries; the 10 year old teases the opponent he just lost to; the 14-year-old tries something that might work for him; and the 17-year-old argues with someone having an opposing view.

These kinds of transformations in the reasons and the reactions are typical of the ones we can identify in the responses we got for the different feelings from children at different ages. There do appear to be gender differences, which we attribute to the fact that boys and girls appear to have somewhat different values. Age-related developmental trends, however, are clearly observed for both genders.

Our emotional development also can be seen as one aspect of the development of our consciousness. To Piaget, consciousness was not a neurological variable but, rather, a mental or cognitive construction. We construct our consciousness, and there are at least four levels, two of which we usually do not recognize as consciousness at all.

If consciousness is a functional continuum of regulations, however, the primary level of consciousness consists of organic-level auto-regulations; the second level of consciousness is the self-regulation of actions without conceptualization. "This system of schemes [of action] constitutes an elaborate "know how" (Piaget, 1976, p. 349). The third level is the level of conceptualization. We construct classes of actions and reasons for these actions. At this level we may not only act, but we also can describe our actions and explain them. The fourth level is the level of reflected abstraction, the level of performing operations on operations. This level is contemporaneous with formal operational thought (typically developed at 11-12 years of age). At this level we can reflect upon our understanding, and we can anticipate the future and make plans. This is the level of self-conscious, (self) regulation - our highest level of consciousness.

Perhaps the most critical facet of our emotional development is our evolving consciousness of the value and personal identity issues in each of our respective emotions. What I have studied is the age-related transformations in what children have in their heads (their consciousness) about these issues.

Somewhere between 3 and 5 years of age, children can share their understanding of the reasons they and others have for their feelings and actions. As they do so, they are revealing the structure and content of their consciousness. Reasons, of course, are cognitions, so it should not be surprising that we found evidence of stage-like transformations in this cognitive material. The stages as we understand them now are as follows: 
Stage

1. Autistic

2. Egocentric Hedonistic

3. Heteronomous I (Getting and Having)

4. Heteronomous II The reasons for feelings usually relate (Going and Doing)

5. Interpersonal I (Belonging)

\section{Content}

The verbal description of reasons is usually bizarre and peculiar. It is often very difficult to recognize needs or values in the subject's verbal responses, but some need for order and continuity, even at the expense of reality, does seem to be involved.

The reasons for feelings relate to pleasure - displeasure, comfort - discomfort, pain - relief, tension relaxation, and to global situations (the weather, the season, or the time of day) or to one's mood. Pleasure, comfort, relief, or freedom from tension are valued.

The reasons for feelings relate to a basic dependence on authority figures. Most of the reasons given at this stage have a passive-receptive theme. Authority figure approval and the things an adult typically gives to a child are valued. Another person may be called a friend, but the friend is viewed as a possession, something one does or does not have.

to going and doing or being restricted in such activities. Adult permission and approval are typically involved. Achievements approved by adults are frequently given as reasons. Other children are valued as companions. Having permission to go places and to do things is highly valued.

Peers are prominent in the reasons for feelings, and how one compares with these peers is frequently an issue. There is considerable emphasis on belonging, so being normal in appearance and behavior is highly valued. Role-taking skills are poorly developed or nonexistent.
This stage could be called the stage of conformity. Persons who are anxious about belonging can be very rejecting to those who are different or who do not conform. This rejection can result in cruel and insensitive actions.

6. Interpersonal II There is an interactive-reciprocal (Mutuality) theme to the reasons for feelings. There is now genuine interaction between self and others. Role-taking skills are well-developed, so the person is sensitive to the feelings of others. Mutuality is highly valued.

\section{Autonomous}

The reasons for feelings reflect the need to be self-defining, self-directed, and autonomous. The person can now reflect upon his or her own actions, thoughts, and feelings. Autonomy is highly valued.

8. Integrated

The reasons given reflect the need to be consistent and honest with oneself and others, of adhering to one's principles and convictions, of being whole and integrated. Integrity is valued.

For most individuals, these stages are achieved sequentially; everyone moves through these stages in the same sequence. With development, the lower stages do not disappear. Rather, they become sub-structures of a larger, more comprehensive structure. The values inherent in the higher stages become a superordinate consideration when values inherent in the lower stages are being confronted. For example, my need for autonomy and integrity may influence how I express my need for mutuality. Having promised to help someone, I may have to renege on my promise when doing what he or she wants me to do to help means the loss of my autonomy or my integrity.

\section{EMOTIONAL MATURITY}

Morse (1982) declared that the goal of affective education was the achievement of affective competence, but he did not define affective competence because, I suspect, he could not do so at that time. I am not sure that I can define emotional maturity in a way that he and others would find acceptable. The work I have been doing has lead me to this conclusion: 
Emotional maturity is not an absense of emotion. It is not the total control of one's emotions so that one is exclusively rational. Emotional maturity means being clear about the personal identity one values, being able to recognize when that identity has been threatened or is being threatened, recognizing and even seeking opportunities to enhance that personal identity - and having that repertoire of actions and economy of affect that will enable one to construct, protect, or enhance that most valued personal identity.

Because personal identity is always a social construction developed in a context of social relationships, emotional maturity has a great deal to do with the development of interpersonal ethics. It has to do with the internalizing of rules and standards for how we treat ourselves and others, which is almost the same thing as saying that it has to do with what we value in our relationship to ourselves and in our relationships with others.

Emotional maturity, then, is having that rich repertoire of emotions that enables us to be most fully human. I consider Stages 6, 7, and 8 as having the essential value ingredients for emotional maturity. Emotions that reflect mutual respect and caring are certainly desirable, and when, in addition to mutuality, autonomy and integrity also are valued and reflected in our feelings, then, in my opinion, there is emotional maturity. Research and theory suggest that by young adulthood a number of people achieve Stage 6. Unfortunately, however, many people are fixated at lower levels.

\section{RESEARCH FINDINGS}

Identifying the stages of emotional development has been a long and arduous task. For the past 20 years, John LeCapitaine and I have been talking with children of different ages about their emotions. Our method of interviewing has varied somewhat; we have asked slightly different questions at various times in our work, but we have consistently asked children about their reasons for their feelings. So, in spite of recently adopted refinements in our method, we have been able to reexamine our basic pool of data whenever this has seemed necessary.

In measuring emotional development, the operation is matching - matching a particular response obtained from a subject to a stage in the sequence of nine stages. Several statistical analyses suggest that our method of assessing stages is essentially reliable, and a number of studies add to our conviction that our theory and our conception of the stages is essentially sound (valid). The reliability of the method was studied by LeCapitaine (1976) and by Dupont (1978a) and by Dupont and Dupont (1979).

Several studies have verified that our method is sufficiently objective so that others can employ it and obtain results very similar to our own. Published studies by Dupont (1978a; 1979), Dupont and Dupont (1979), LeCapitaine (1987), and Sprinthall and Burke (1985), and unpublished studies by Chisholm (1980), Fasching (1976), Foster (1988), and Hahn (1986) have all contributed to the growing body of data on the construct and predictive validity of our stage-referenced method of measuring emotional development.

These studies have produced several interesting conclusions about emotional development and its modification. For example:

- Although there is clearly a relationship between ages and stages, at any age a number of children are delayed in their development, and always a few children functioning at higher stages than most of the children in their age group. As age progresses, the percentage of children fixated at lower stages increases.

- The results of one study suggest that children with behavior disorders function at a lower stage of emotional development than do their "normal" peers (Fasching, 1976).

- Socially isolated, noninteractive junior high students were found to be functioning at a lower stage of emotional development than their more socially active peers (Chisholm, 1980).

- In a study comparing the cognitive, interpersonal, and emotional domains of development in children at 8,9 , and 10 years of age, support was found for the notion that development is sequential in all three domains during this age period. But no significant correlation between domains was found, suggesting that development may be domain-specific in this age range (Sprinthall \& Burke, 1985). 
When the effectiveness of an affective education program for grades 6 through 8 (ages 12 through 14) was studied comparing emotional development stage scores and IQ scores before and after participating in the program, similar results were found. At pretest, IQ and emotional development were not significantly correlated, but at posttest a low but significant correlation was obtained between IQ and emotional development. This suggests that intelligence does not influence emotional maturity until a deliberate effort is made to facilitate students' emotional development - to help them think about feelings and their social relationships (Dupont \& Dupont, 1979).

- Both Hahn (1986) and Foster (1988) found that peer counseling experiences have a favorable impact on emotional development.

- LeCapitaine (1987) found that for children grades 3 and 4, a curriculum combining affective education activities and moral development activities had a very significant positive impact on the development of moral judgment when compared to either affective education or moral development activities alone. Both moral development and affective education activities had a favorable impact on emotional development.

All three of these studies suggest that it is possible to measure emotional development. They also suggest that providing students with experiences that focus on feelings and that provide for increased social interaction have a favorable impact on emotional development. Moral judgment also is improved when such experiences are provided for children.

Our studies of what children have in their heads as reasons for their feelings also strongly suggest that emotional development is a social phenomenon because between 5 and 15 years of age, there is a convergence toward a limited number of reasons for each feeling. With development and socialization in a particular social system, we apparently increasingly share a system of meaning sanctioned by that social system. This should not surprise us, because without a system of shared meaning, we could not communicate at all. Our reasons for our feelings, and what we do when we feel as we do, comprise a very important part of the meaning we share with our peers.

My colleagues and I have not studied the action component of selected emotions as systematically as we have studied reasons for feelings, but we do have some evidence showing that older children are more active, assertive, and creative in dealing with situations and events associated with sadness, anger, and guilt. There is also evidence that even before they are 10 years of age, some children recognize that there are things they can deliberately do to make themselves and others happy or proud, or to prolong these positive feelings.

\section{IMPLICATIONS FOR THE EMOTIONAL DEVELOPMENT OF EXCEPTIONAL CHILDREN}

These findings all fit nicely into the Piagetian child development paradigm. Piaget, who was perhaps the most brilliant and creative developmentalist to live in this century, stressed the importance of social experience and selfregulation for development. He also stressed the importance of interacting and communicating with others, giving careful attention to the feedback we get from them, and making changes in our actions toward them that facilitate constructive social relationships (Piaget \& Inhelder, 1969). Over time, we develop those actions and feelings that enable us to be comfortable in the groups to which we belong.

Early in life children develop those actions and feelings that are adaptive to their family situations. Later they develop those actions and feelings that are adaptive to their school situations. Later still they adapt to the adult world. If the emotional-social climate in any one of these situations (subcultures) is very different from the others, children will experience stress and discomfort in that situation and will continue to do so until they can make the necessary adaptations.

Interpersonal communications and the processing of feedback are essential for emotional development, and this is why I am so concerned about the emotional development of exceptional children and youth. Many exceptional persons have disabilities that hamper their interpersonal communication. If they cannot hear others, or if their behavior is disturbing to others, or if they cannot process the feedback they get from others, their adaptation and development may be seriously jeopardized. 
It is also possible that the way others respond to their exceptionality may hamper communications, and therefore hamper development. If others are too protective or if they are rejecting, this may have serious and often unrecognized consequences for their development. A curriculum that gives too much emphasis to individual work and achievement and too little attention to group and cooperative activities also can hamper the exceptional person's emotional development.

For example, when we provide an adolescent who has a learning disability with a program that is completely individualized, we are doing something very detrimental to the student's emotional development. This is especially unfortunate because many adolescents with learning disabilities are delayed in their emotional-social development to begin with. Emotional development is not facilitated by social isolation!

These concerns have culminated in 20 years' work developing and testing programs to stimulate and facilitate emotional development. One program, Toward Affective Development (TAD) (Dupont, Gardner, \& Brody, 1974), is designed for middle and upper elementary level students. A second program, Transition (Dupont \& Dupont, 1979), is designed for middle and junior high school level students. Both programs have these goals and educational strategies in common:

- a deliberate effort to stimulate and facilitate development rather than leaving development entirely to chance.

- a strong emphasis on providing or simulating real life, person-to-person experiences for students a learning by participation approach.

- an emphasis on the reflective evaluation of experience. Following structured activities, or in conjunction with activities, students discuss their experiences in small groups or in teacher-guided class discussions.

- an emphasis on noncompetitive, cooperative efforts. Students interact with one another in a climate of acceptance, respect, and mutual appreciation. There is a deliberate effort to strengthen empathy and actions that balance personal and social considerations.
Both programs structure an atmosphere of acceptance and respect and provide for extensive discussion of experience. Each program's activities are organized into units to facilitate their integration into the traditional curriculum.

Having spent many years in local and statewide mental health programs, and recognizing the need for programs that focus on prevention rather than just treatment, I had hoped that the publication of Toward Affective Development (TAD) and Transition would encourage the acceptance, design, employment, and evaluation of a more comprehensive curriculum - one that would foster not only basic skill development but emotional development as well. The reality that a stage-referenced method of measuring emotional development is now feasible may yet make this hope a reality. In another paper (Dupont, 1978b), I have voiced a concern that the mainstream "back to basics" curriculum, which gives so little attention to needs, values, and feelings, may be detrimental to the emotional development of exceptional children, if not to all children.

The sad truth of this statement was again brought to my attention by a recent article in the Atlanta JournalConstitution (Fuller, 1989). Latashia Pinkett, a seventh grader, celebrated her 13th birthday in late November, 1988 , followed by a very happy Christmas. She got all the gifts she had told her parents she wanted for both occasions. But on January 5, Latashia searched for the gun her father kept hidden in a rarely used cabinet, went to the backyard, and shot herself in the face. The face! Why? Latashia left two notes - one for the police and one for her family. In the note to the police, she explained that her family had nothing to do with her action. In the note to her family, she attempted to explain why she was taking her own life. Latashia was unusually tall for her age, 5 feet 10 inches - taller, of course, than all of her schoolmates. The kids made fun of her and teased her constantly about her height.

According to Mrs. Pinkett: "They would call her 'tree.' They would tell her she was ugly and that she would never have a boyfriend ... The note said she couldn't take the name-calling, the pressure, any more. She couldn't face going back to school, the kids in school, or her teachers."

Her mother continued: "I'm tall myself. It runs in the family, so I know what she was going through with the teasing. But even her teachers said they didn't know how much she must have been hurting ... The note made me understand that Latashia thought people hated her because of her height and the way she looked. She said she was dif- 
ferent and was always going to be different. She just couldn't fit in, so she was going to get out of the way."

Isn't it hard to think of children being that cruel to one of their peers? It surely is, but we know from our understanding of the stages of emotional development that there is a downside to the stage of belonging. Some children become so anxious about belonging that they become rigid conformists who are very rejecting, often cruelly so, of children who are different or do not conform. They can do this and not feel guilty or ashamed because their role-taking skills are poorly developed and, therefore, they are not sensitive to the feelings of the child they are rejecting.

In designing TAD, we were very aware of this developmental phenomenon, so in Section III we included several activities to increase students' understanding of the feelings and needs of their handicapped (exceptional) peers, or students who are different from themselves. In one activity, the teacher shows the class a picture of a boy who has a brace on his leg. He is standing with a group of his peers. The teacher then structures the following situation:

Can everyone see the boy in this picture? His name is Mike. Notice that he has a brace on his leg. The weakness in his leg is only partly corrected by the brace. Mike can walk with just a slight limp, but he cannot run very well. $\mathrm{He}$ used to try to run, but he fell down a lot, and so he doesn't like to try any more. However, Mike can see very well. He is well coordinated, and he is very smart. Most of the boys like him. Even though he can't run, Mike really wants to play baseball with the rest of the guys, but lately he has noticed that he has been the last one chosen when the gang chooses up sides to play ball. (Dupont, Gardner, \& Brody, 1974, pp. 183-184)

The teacher then leads a discussion of the following questions:

1. How do you think Mike feels?

2. What are his reasons for wanting to play ball?

3. The boys know that Mike cannot run, but he really wants to play baseball with them. Here are some things they might do:

a. They might get irritated because Mike wants to play and may say to him, "Well, okay, come on and play if you really want to." If they spoke to him that way, what do you think would happen? b. They might ask Mike to be their coach instead of a player in the game. If they did this, what do you think would happen?

c. They all like Mike, so they might ask him to play in the game anyway. If they did this, what do you think would happen?

4. Can you think of any other things they might do? (Discuss students' suggestions.)

5. Can you think of a time when a person wasn't physically able to join in an activity? What happened? (p. 184).

In his evaluation of Units 12 and 13 of TAD, Tramontozzi (1977) found that $85.7 \%$ of the students participating in the above activity (which takes approximately an hour) thought it was interesting, and $92.8 \%$ of the students said they learned something. When asked to describe what they had learned, the students made comments such as: "Being handicapped doesn't matter" and "handicapped people can do the same as us." In his observations of the students' reaction to the activity, Tramontozzi made the following comments: "Enthusiasm to participate was high, and it seemed that the class as a whole was eager. I think the concept and the objectives of this lesson are excellent for this age group (grades 3-6)" (summary page, Lesson 109).

TAD and Transition include additional activities of this kind. The teacher presents a series of pictures that tell a story, or provides a story that may be either read or heard. The students then are asked to identify the conflict, suggest alternative resolutions, and discuss the probable consequences (including the feelings of those involved) of each alternative.

These kinds of activities do seem to increase students' understanding of others, including persons with exceptionalities and handicaps. TAD and Transition model these activities but cannot be, in themselves, a sufficient increment to correct what I believe to be a very serious curriculum deficiency - activities that help students develop understanding, acceptance, and interpersonal skills. The current practice of teaching exceptional students social skills so they will be more acceptable to their nonexceptional peers seems to me to be a case of blaming the victim.

Surely if we are going to keep the exceptional student in the mainstream, we must do what we can to make the mainstream a hospitable environment for the exceptional student. The environment wasn't hospitable for Latashia Pinkett, whose height of 5 feet 10 inches made her 
an exceptional student. I suspect that thousands, if not hundreds of thousands, of students are like Latashia - too thin, too thick, too short, too tall, too light, too dark, too slow, too excitable, too this, or too that - for them to be safe from the pre-adolescent's obsession with normality and conformity.

I believe we can do something about this destructive phenomenon. Surely it starts with the recognition that teachers do have a major responsibility for the emotionalsocial climate of their classrooms. Surely we also can say that teachers have some responsibility for how students treat one another in their classrooms. The students are there in a group because the teacher, as an agent of the school board, wants them there as a group. It follows, then, that the teacher has a major responsibility for the functional effectiveness of the group. A few minutes of counselortaught guidance activities, a little social skill instruction for the exceptional students, just won't do it. We have got to improve the emotional-social climate in the mainstream if we are going to place or keep exceptional students there!

Have we prepared the classroom teacher for this responsibility? Those of us who are seriously committed to affective/psychological education believe we have some ideas on how this can be done. TAD and Transition were designed with this purpose specifically in mind. Both programs model what I and others believe could be done.

Isn't it urgent that we take this issue seriously and that we challenge the mainstream teacher to face this issue? Shouldn't we be discussing this issue in symposia and workshops so that we can then research all viable hypotheses about how to achieve the objective of making all classrooms a hospitable place for all children - and especially the Latashia Pinketts of this world?

Let's integrate our compassion and our criticalanalytical and research skills into a serious effort to address this challenge. No new rush to restore the fad of affective education, please. This time, a long-term commitment to solving a recognizable, describable problem is needed.

\section{REFERENCES}

Arnold, M. (1960) Emotion and personality: Vol. I. Psychological aspects. New York: Columbia University Press.

Averill, J.R. (1980). The emotions. In E. Staub (Ed.), Personality: Basic aspects and current research (pp. 134-199). Englewood Cliffs, NJ: Prentice-Hall.

Beck, A.T. (1976). Cognitive therapy and the emotional disorders. New York: New American Library.

Chisholm, E.B. (1980). Developmental differences between socially interactive and non-interactive junior high school students. Unpublished master's thesis, University of Minnesota.

Dupont, H. (1978b). Meeting the emotional-social needs of children in the mainstream environment. Counseling \& Human Development, 10, 1-11.

Dupont, H. (1978a). Affective development: A Piagetian model. In Proceedings of the eighth annual conference, Piagetian theory \& the helping professions (pp. 64-71). Los Angeles: USC Bookstore.

Dupont, H. (1979). Affective development: Stage and sequence (a Piagetian interpretation). In R.L. Mosher (Ed.), Adolescents' development and education (pp. 163-183). Berkeley: McCutchan.
Dupont, H. (1989). Emotion and emotional development. Unpublished manuscript.

Dupont, H., \& Dupont, C. (1979). Transition. Circle Pines, MN: American Guidance Service.

Dupont, H., Gardner, O.S., \& Brody, D. (1974). Toward affective development (TAD). Circle Pines, MN: American Guidance Service.

Fasching, S. (1976). A comparison of normal and behavior disordered children on a measure of affective development. Unpublished master's thesis, University of Wisconsin-Eau Claire.

Foster, E.S. (1988). A cognitive development approach to training elementary school helpers. Unpublished doctoral dissertation, North Carolina State University

Fuller, C. (1989). Teenage suicide in a time of plenty: Are we listening hard enough? Atlanta Journal \& Constitution, January 16.

Hahn, J.A. (1986). The impact of a high school peer counseling training program upon the affective development, ego development, and self-concepts of peer counselors. Unpublished doctoral dissertation, Boston University.

Lazarus, R.S. (1982). Thoughts on the relations between emotions and cognition. American Psychologist, 37, 1019-1024. 
Lazarus, R.S. (1984). On the primacy of cognition. American Psychologist, 39, 124-129.

Lazarus, R.S., Kanner, A.D. \& Folkman, S. (1980). Emotions: A cognitive phenomenological analysis. In R. Plutchik \& H. Kellerman (Eds.), Theories of emotion (pp. 189-217). New York: Academic Press.

LeCapitaine, J. (1976). Statistical reliability of the affective development test. Unpublished manuscript.

LeCapitaine, J. (1987). The relationship between emotional development and moral development and the differential impact of three psychological interventions on children. Psychology in the Schools, 24, 372-378.

Morse, W.C. (1982). The place of affective education in special education. Teaching Exceptional Children, 14, 209-211.

Piaget, J. (1976). The grasp of consciousness. Cambridge, MA: Harvard University Press.

Piaget, J. (1969). The psychology of the child. New York: Basic Books.

Sprinthall, N.A., \& Burke, S.M. (1985). Intellectual, interpersonal, and emotional development during childhood. Journal of Humanistic Development, 24, 5058.

Tramontozzi, J. (1977). Toward affective development: A field test on Section III-Units 12 and 13. Unpublished paper, University of Windsor.

\section{Professional update}

\section{NEW BOOKS}

\section{Improving Basal Reading Instruction}

Edited by Peter N. Winograd, Karen K. Wixson, and Marjorie Y. Lipson

The thesis of this new book is that basal readers are most effective when they are used flexibly and as part of a total, unified program of reading instruction. Although basal reading programs are the most common means of teaching reading, there is a dearth of complementary literature offering comprehensive, constructive suggestions on how to integrate basals into effective programs. This book helps to fill that gap.

Among the topics covered are: basal selection; grouping and pacing with basal materials; individualizing within basal instruction; integrating seatwork with the basal lesson; student evaluation; integrating writing and reading instruction; and providing a bridge to children's literature.

The book includes essays by some of the foremost researchers in the field of reading instruction; yet it is essentially practical and implementable. It should be of interest in both preservice classes (reading methods courses) and to inservice teachers.
This 320-page book, available in both paper and hardbound, is published by Teachers College Press, Columbia University, New York, NY 10027.

\section{Generalization for Students \\ Edited by Norris G. Haring}

Here is a new book presenting some very specific data and strategies employed with learners having moderate, severe, and profound handicaps in the state of Washington. Its primary objective is to provide educators with a means of systematically eliminating skill generalization problems. Second, the book presents information on the empirical basis for the strategies.

The second section will be most useful for those involved in implementation. Chapters include material on writing objectives for generalization, probing skill use, decision rules and procedures, and incorporating the strategies into IEPS.

This book has benefited from the input of many people and school districts. It has a solid foundation in research over a 5-year period, involving hundreds of students. The bottom line is that the selected strategies improved generalization to $88 \%$ of the skills learned.

For further information and ordering, contact: University of Washington Press, P.O. Box 50096, Seattle, WA 98145. 


\section{xcellence in Educating he Gifted}

ohn F. Feldhusen, Purdue University

oyce L. VanTassel-Baska, College of William

nd Mary

en R. Seeley, Clayton College (Denver)

\section{RONHYIDTPONACO8\%}

he highest satisfaction in life comes to those who use their ilities and talents to the fullest extent and who create new leas, inventions or works of art. Thus, this book was conived to delineate the many facets of gifted individuals nd their learning patterns, so that they may be enabled to ach their greatest potential.

n expansion of an earlier, well-respected text, this book mains in the vanguard of gifted education. It offers a mprehensive introduction to the key topics, issues, and

\section{PDCLALDDAVURDST}

Points out major study results - Terman and Oden, the Marland Report, Leadership Training Institutes

Discusses issues and controversies, including the "pull-out" resource room model

Addresses concerns about enrichment, acceleration, individualization

Emphasizes the roles of facilitators - teachers,

counselors, mentors

\section{DNHDIST}

1 Introduction

\section{art I The Gifted and Individual Differences}

2 Characteristics and Needs of the Gifted

3 Underachieving and Handicapped Gifted Learners

4 Gifted Girls

5 Disadvantaged Gifted Learners

6 The Highly Gifted

7 Identification and Assessment of the Gifted

\section{art II Program Development}

8 Program Models for Gifted Education

9 A Comprehensive Model of Gifted Program Development

0 Evaluating Programs for Gifted Learners

1 Key Administrative Concepts in Gifted Program

Development controversies in the field. Major topical areas include: the nature of giftedness; specific gifted subpopulations; identification processes; program development; curriculum and instruction, and facilitators (teachers, counselors, mentors).

Contributors to the book are experts in the field, offering insights from both research and experiential backgrounds. Specific methods and strategies, based on strongly developed philosophical underpinnings, give practical teaching suggestions to help the beginning and experienced educator.

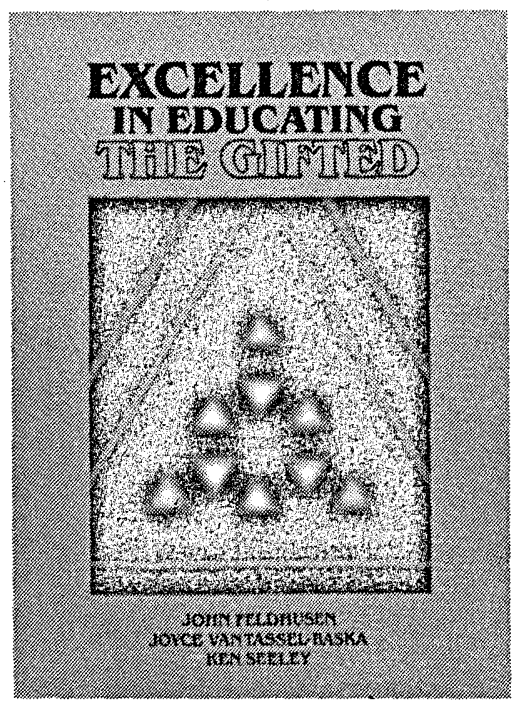

Part III Curriculum and Instruction

12 Appropriate Curriculum for the Gifted

13 Math and Science Curriculum for the Gifted

14 Social Studies and Language Arts for the Gifted

15 Arts and Humanities for the Gifted

16 Thinking Skills for the Gifted

17 Instructional Methods for the Gifted

Part IV Helping the Gifted Achieve Excellence

18 Facilitators for Gifted Learners

19 Counseling the Gifted

20 Synthesis

8901/hardbound/ISBN 0-89108-205-0 


\section{AUTHOR INDEX}

Bauer, Anne M. (November 1988)

Chrystal, Charles A. (December 1988)

Dupont, Henry (May 1989)

Edgar, Eugene (September 1988)

Epstein, Michael H. (April 1989)

Graham, Steve (February 1989)

Johnson, Lawrence J. (December 1988)

Johnson, LeAnn A. (February 1989)

Keller, Clayton E. (March 1989)

Lloyd, John Wills (March 1989)

Mercer, Cecil D. (October 1988)

Patton, James R. (April 1989)

Peterson, Susan K. (October 1988)

Polloway, Edward A. (April 1989)

Prieto, Alfonso G. (January 1989)

Pugach, Marleen C. (December 1988)

Ross, John (October 1988)

Shea, Thomas M. (November 1988)

Smith, Thomas E.C. (April 1989)

Whitaker, Joseph H. (January 1989)

\section{CHRONOLOGICAL INDEX OF TITLES}

Employment As an Outcome for Mildly Handicapped Students: Current Status and Future Directions (September 1988)

A University-Based Model of Multidisciplinary Services to Exceptional Students and Related Professionals (October 1988)

Structuring Classrooms Through Levels Systems (November 1988)

Rethinking the Relationship Between Consultation and Collaborative Problem-Solving (December 1988)

Teacher Management and Helping Style: How Can We Develop Student SelfControl (December 1988)

The Effects of Cultural and Linguistic Variables on the Academic Achievement of Minority Children (January 1989)

Teaching Reading to Learning Disabled Students: A Review of ResearchSupported Procedures (February 1988)

Effective Mathematics Instruction: Development, Instruction, and Programs (March 1989)

Comprehensive Curriculum for Students with Mild Handicaps (April 1989)

The Emotional Development of Exceptional Students (May 1989) 